\title{
O PAPEL DO CRONISTA E O LUGAR DA CRÔNICA NO JORNAL
}

\section{Janete Terezinha Ferron ${ }^{1}$}

\begin{abstract}
Resumo
O objetivo deste trabalho é discutir acerca do discurso jornalístico e o lugar da crônica nesse contexto da mídia. Para tanto, evidenciam-se conceitos sobre os gêneros discursivos e a constituição híbrida da crônica. No que tange à reflexão sobre sua "efemeridade" no jornal e a posterior publicação em livro, são elencadas para análise algumas crônicas de Carlos Heitor Cony.

Palavras-chave: Crônica, literatura brasileira, jornalismo, hibridismo discursivo, Carlos Heitor Cony.
\end{abstract}

\section{Abstract:}

The objective of this paper is talk over journalistic discourse and about the chronicle position on media context. For this, show up on the concepts about the discursive kinds and hybrid conceptions of the chronicle. Regarding the consideration of their "short-lived" in the newspaper and later publication on book, it is listed some chronicles of Carlos Heitor Cony for analysis.

Keywords: Chronicle, Brazilian literature, journalism, discursive hybridism, Carlos Heitor Cony.

\section{Entre a literatura e o jornalismo}

Muito além do chamado "conteúdo", a crônica significa toda uma parcela valiosa de uma época e este aspecto torna-se mais precioso por ser o resultado de uma subjetividade exercida cotidianamente: o território da crônica conseguiu manter-se o mais "independente" possível de normas internas e coerções dos manuais de redação do jornalismo brasileiro. Para alguns, a crônica não se encaixa como notícia - mas ela faz dos fatos seu enredo e das pessoas comuns suas personagens. Para outros, sua linguagem e seu estilo próprios não permitem que ela seja simplesmente jornalismo, seria mais que isso, seria literatura. A que gênero, então, poder-se-ia classificar a crônica? Jornalístico ou literárioº ${ }^{2}$ ?

Essa é uma dúvida que está presente em muitos estudos, ensaios e teses sobre a crônica brasileira, divide escritores, jornalistas e até mesmo os próprios cronistas. Alguns, embora considerem a crônica um gênero literário, apontam o seu caráter efêmero. Outros afirmam que ela apenas utiliza os recursos da literatura para fazer jornalismo. Há também aqueles que

\footnotetext{
${ }^{1}$ Professora do Departamento Acadêmico de Comunicação e Expressão da UTFPR e Doutoranda em Letras pela UFPR.

${ }^{2}$ Em conformidade com Bakhtin (1979), nessa tentativa de classificar a crônica como gênero "jornalístico" ou "literário" não pressupomos que exista apenas um gênero jornalístico e somente um literário. Estamos entendendo que o editorial, a notícia, a reportagem etc., presentes no jornal, constituem-se gêneros distintos. O mesmo ocorre com a literatura que engloba diferentes gêneros: o romance, o conto, a poesia, dentre outros. O que pode ocorrer com a crônica é, por vezes, uma aproximação maior com o jornalístico ou com o literário. Apesar disso, a polêmica persiste e ainda gera discussões - daí trazermos a questão para nosso trabalho.
} 
desistiram de classificá-la como gênero homogêneo, atribuindo-lhe natureza híbrida (COUTINHO, 1983, p. 304-06):

Enquanto o jornalismo tem no seu fato seu objetivo, seu fim, para a crônica o fato só vale, nas vezes em que ela o utiliza, como meio ou pretexto, de que o artista retira o máximo partido, com as virtuosidades de seu estilo, de seu espírito, de sua graça, de suas faculdades inventivas. A crônica é na essência uma forma de arte, arte da palavra, a que se liga forte dose de lirismo (Idem, p. 305).

A polêmica existe porque a crônica brasileira nasceu no folhetim do século XIX para ser publicada no jornal. Uma das linhas do Romantismo - aquela mais idealizada da realidade - contribuiu, em parte, para que o acento lírico pesasse sobre a crônica desde as suas primeiras manifestações. Ambientada na imprensa, ela se alimentou de notícias, digeriu fatos e ganhou consistência de texto jornalístico. Porém, pode-se dizer que em alguns casos, para a crônica, o fato ou a notícia só valem quando podem ser utilizados como meio ou pretexto do qual o escritor, com seu estilo e criatividade, retira o máximo partido (id. Ibid.).

O escritor Carlos Heitor Cony insinua que a crônica é um gênero literário menor, mas a linguagem e o estilo fazem a diferença. E, é por meio da própria crônica, que ele fala sobre esse gênero de texto:

\footnotetext{
Alunos do Curso de Comunicação pedem-me uma definição do jornalismo literário e, em complemento, o papel da crônica nesse tipo de jornalismo. Embora não me considere a pessoa indicada para falar sobre o tema, tentarei dar uma resposta coletiva ao que me pedem, com as naturais ressalvas sobre a autoridade (nenhuma) com que me meto nesta praia, que não é a minha.

Para definir o jornalismo literário, vamos começar pelo substantivo, que é jornalismo, deixando o adjetivo para depois. O que é o jornal? É um periódico, uma coisa feita de período em período. Por mais que pareça incrível, Franz Kafka, que nunca foi realmente um jornalista, tem a imagem mais perfeita que conheço sobre o assunto. Ele compara o jornal a um trem que sai todo dia, num determinado horário, vazio ou cheio, e de determinada plataforma, para chegar a outra. Se estiver lotado, tudo bem. Se estiver com lugares vazios, dará prejuízo, porque cada lugar sem passageiro não poderá ser reciclado, usado uma segunda vez.

Em países subdesenvolvidos, espera-se o trem encher, como um lotação, um pau-dearara. Uma ferrovia civilizada faz o trem cumprir o horário, independentemente de estar cheio ou com lugares vazios.

O jornal é como um trem — dizia Kafka. Tem que sair em determinado dia, ou todos os dias, mas com uma diferença básica em relação aos trens: ele não pode sair vazio. Com assunto ou sem assunto, tem que ocupar todas as suas páginas, seja com anúncios, ilustrações ou textos paralelos, desvinculados de sua função natural, que é a notícia, a informação, o serviço da comunicação propriamente dito.

O veículo-jornal, ao contrário do veículo-trem, não pode sair com lugares não ocupados. E, para encher com alguma dignidade o ângulo morto de cada edição, apelou-se, entre; outras coisas, para a crônica, que tem uma tradição paralela na história da comunicação humana.

Nos séculos 16 e 17, a crônica era um gênero-bonde, um gênero-ônibus, onde tudo cabia com o nome de crônica. Qualquer relato levava o nome de crônica, que tem embutido o conceito de tempo (cronos), cobrindo um período, sendo, portanto, um periódico.
} 
Voltemos agora ao jornalismo dito literário. A literatura é, em essência, o oposto do período, do tempo. Ela procura ser intemporal, sem vínculo com a data — nada mais frustrante do que a literatura datada.

Daí a conclusão de que a crônica, como gênero jornalístico ou como gênero literário, é uma contrafação.

Os mais radicais poderão considerá-la subjornalismo ou subliteratura. Dirão alguns: há crônicas admiráveis, e a citação de Machado de Assis é obrigatória. E cada um poderá citar um autor ou uma determinada crônica admirável. Mas, se Machado não tivesse escrito os romances finais de sua carreira, seria hoje um João do Rio melhorado, um Humberto de Campos mais consistente.

Contudo não podemos ignorar que foi nos Jornais, aqui e em outros países, que, para ocupar lugares vazios, os editores procuravam autores de textos exclusivamente literários, sem compromisso com o período, com a data. Em jornal, Manuel Antônio de Almeida publicou as "Memórias de um Sargento de Milícias". Em jornal, saiu "O Guarani", de José de Alencar. Grosso modo, o folhetim, mesmo com sua carga pejorativa, seria o padrão do jornalismo literário, o passageiro disponível que ocuparia o lugar de uma notícia, de uma informação, de um serviço.

Antes da existência dos jornais, a comunicação era feita por arautos ou mesmo por camadas de fumaça, à maneira dos índios, ou por sinais luminosos. Não corria o risco de ser confundida com a literatura. Quando os sinais foram codificados em palavras compostas por letras, a aproximação com a literatura tornou-se inevitável.

Mas a notícia, base do jornal, é como a anedota em que Guimarães Rosa a comparava ao fósforo que se acende, brilha um instante e se apaga. Torna-se inútil como um fósforo queimado. Não funciona uma segunda vez.

Comprometido com a notícia, com o fato do dia, o jornal abriu espaços para a comercialização, que o sustenta industrialmente, e para os passageiros robotizados que podem ocupar os lugares vazios de cada edição. Surgiram então as colunas, os "potins", os "faits divers", as charges e, naturalmente, as crônicas, que são a expressão mais visível do jornalismo dito literário. Daí que os cronistas, mesmo os bemsucedidos, são vistos como subprodutos, autores de circunstância que, mais cedo ou mais tarde, ficarão datados.

Resumindo a ópera: pode-se concluir que não há jornalismo literário. Há jornalismo e há literatura. Funcionam por meio de sinais ou símbolos, que são as palavras compostas por letras, mas nem todas as letras formam necessariamente aquilo que se compreende como literatura.

Há jornalistas que dominam a técnica e a composição do texto. Mas são eles, exatamente, que se tornam cada vez melhores à medida que deixam de ser literários. (CONY, A crônica como gênero do jornalismo e da literatura. In: Folha de S. Paulo, 06/12/02: E-16).

Antonio Candido (1992), em ensaio considerado clássico sobre o tema, aponta que uma das mais importantes funções desse "gênero menor" é a de ajudar a estabelecer ou restabelecer a dimensão das coisas:

Em lugar de oferecer um cenário excelso, numa revoada de adjetivos e períodos candentes, pega o miúdo e mostra nele uma grandeza, uma beleza ou uma singularidade insuspeitadas. [...] não tem pretensões a durar, uma vez que é filha do jornal e da era da máquina, onde tudo acaba tão depressa. [...] a sua perspectiva não é a dos que escrevem do alto da montanha, mas do simples rés-do-chão (CANDIDO, 1992, p.14).

Para Candido, a crônica moderna firmou-se no Brasil nos anos 30, quando ainda a profissão de jornalista não estava regulamentada e grande parte dos profissionais que atuavam nos jornais era composta por escritores. É nessa fase que surgem nas redações nomes como 
Mário de Andrade, Manuel Bandeira, Carlos Drummond de Andrade e Rubem Braga, que se voltou quase exclusivamente ao gênero, após 10 anos atuando como repórter. Em todos os cronistas, Candido vê um traço comum:

(...) deixando de ser comentário mais ou menos argumentativo e expositivo para virar conversa aparentemente fiada, foi como se a crônica pusesse de lado qualquer seriedade nos problemas. (...) É curioso como elas mantêm o ar despreocupado, de quem está falando coisas sem maior conseqüência; e, no entanto, não apenas entram fundo no significado dos atos e sentimentos do homem, mas podem levar longe a crítica social. (...) Quero dizer que por serem leves e acessíveis talvez elas comuniquem mais do que um estudo intencional a visão humana do homem na sua vida de todo o dia (CANDIDO, 1992, pp.17-19).

Parece-nos que o cronista assume, no mínimo, duas visões: num primeiro momento, de alguém que vê - extremamente atento ao tempo - os fatos e faz da crônica uma membrana sensível capaz de registrar a moda, os costumes, as mudanças, novas expressões e termos, a novidade e as marcas do tempo que são as notícias; e numa segunda visão, tem-se o olhar de alguém que julga, critica, faz o leitor pensar.

\section{Heterogeneidade Genérica: a crônica como contraponto à objetividade no jornalismo}

De acordo com noções apresentadas e o conceito bakhtiniano sobre os gêneros discursivos $^{3}$, pensamos que a crônica contemporânea pode ser compreendida como uma zona de miscigenação do discurso jornalístico com várias outras formas discursivas, provocando um grande diálogo de pensamentos nos veículos de comunicação.

Respondendo à rigidez e uniformidade que se dá no jornal ao material lingüístico e constituindo-se num gênero heterogêneo e flexível, ao contrário dos gêneros jornalísticos que se firmam pela identidade - editorial, reportagem, artigo de fundo etc. - a crônica usa e abusa da variedade de gêneros, dos simples aos mais complexos, na sua composição: diálogo do cotidiano, retratos, tipos, cenas cômicas e dramáticas, versos, sonetos, relatos, narrativas, comentários, contos, confissões, descrições líricas, sátiras, paródias, dentre outros, constituindo-se em discurso híbrido.

\footnotetext{
${ }^{3}$ Para compreender a construção de um enunciado é preciso considerar tanto o fato de estar inter-relacionado com outros enunciados (interdiscursividade), quanto o fato de que está em ligação com a situação social que o provoca. Em Os gêneros do discurso e O problema do texto Bakhtin (1979) discute o vínculo entre o intercâmbio comunicativo social e a interação discursiva. É nas diferentes esferas da práxis humana que se originam os enunciados, que refletem as condições específicas de sua constituição pelo seu tema, seu estilo (recursos léxicos, fraseológicos e gramaticais) e sua composição (formas de composição e acabamento dos enunciados). Aos diferentes tipos de intercâmbio social correspondem diferentes tipos de enunciados, que, historicamente, constituem formas "relativamente estáveis" de enunciados, os gêneros discursivos.
} 
Dentro dessa perspectiva, a crônica moderna traz em si o imaginário de uma época, pois tem nos seus autores - antes de mais nada - leitores argutos do seu tempo e capazes de produzir memória. Assim, muitos são os estudos, nas mais diversas áreas, os quais tratam a crônica como uma forma diferenciada de documento para o pesquisador implementar suas análises sobre determinada época.

Se por um lado, a notícia e os demais gêneros do jornalismo buscam muitas vezes a conclusão, tentam oferecer ao leitor uma história clara, concisa, em que a objetividade tem a pretensão de esgotar os fatos por meio do relato imparcial, a crônica parece ir a um sentido oposto. Acreditamos que a presença da crônica funcione como uma espécie de perturbação junto ao critério de "veracidade" estabelecido pelo jornal. Perturbação que transfere, em certa medida, para o jornal a qualidade da incompletude - característica da literatura que problematiza o real - provocando uma abertura na pretensão jornalística de dar conta da totalidade dos fatos e de esgotar as discussões. Com essa abertura, o jornalismo ganha em complexidade e o leitor, obviamente, é presenteado com a possibilidade de enriquecer uma leitura que em princípio seria meramente funcional e mesmo ingênua.

Os fatos e o tempo presentes são a matéria-prima do jornal, que os extrai do seu contexto e os organiza num formato, muitas vezes, padronizado e despersonalizado, acessível a um leitor-observador que os consome rapidamente. A palavra do jornalismo age como mediadora da nossa ligação com o mundo, transformando os fatos em acontecimentos, que são reconhecidos por meio dos relatos da atualidade. A notícia está quase sempre no presente. Os fatos de ontem são substituídos pelos de hoje e, na época da Internet e televisão em tempo real, pelos fatos da última hora. Daí a característica quase essencial do jornal: efemeridade.

É com os fatos e com a atualidade que a crônica coloquial se constitui, explorando sua provisoriedade, concretude e singularidade para, simultaneamente manter e ultrapassar esses elementos.

Davi Arrigucci Jr. (1987) caracteriza a crônica como o espaço em que o jornal entra em tensão com o que não é informação nem transitoriedade, o que torna algumas crônicas aparentemente incompatíveis com a modernidade do jornal, que significa rapidez e superficialidade.

No entanto, a crônica - que se origina de cronos, tempo - é também um tipo de gênero que mais se aproxima dessa rapidez própria da técnica e do consumo. Nascida nos rodapés dos jornais e fruto da simplificação da linguagem, ela se aproxima do cotidiano e aproxima os fatos da sensibilidade do leitor (Candido, 1992, p. 7). No Brasil, sua evolução, a partir dos artigos sobre as questões do dia publicados no século XIX, incorporou aos poucos características como 
a leveza, a brevidade, a disposição de divertir sem preocupação de informar, o humor, a narrativa aparentada à ficção dos contos ou a exposição que chega perto da poesia. Outras vezes, porém, a crônica mantém-se fiel aos fatos, marcando, como destacamos anteriormente, toda uma época.

Como exemplo do tratamento atual da crônica pelos jornais brasileiros, tomamos a Folha de S. Paulo que dedica grande espaço à crônica. São várias crônicas publicadas diariamente cujo enfoque é a política, economia e o social, além das que tratam de esportes e as de final de semana as quais são editadas em cadernos especiais, bem como os ensaios e resenhas que também privilegiam a subjetividade.

Subjetividade esta que, segundo Carlos Eduardo Lins da Silva (1991), tendeu a ser banida do texto jornalístico desde a modernização da imprensa brasileira, em conformidade com o padrão norte-americano de objetividade, a partir dos anos 50. O jornalismo passou a buscar um texto informativo, direto, enxuto, padronizado e não opinativo. Essa tendência, segundo o autor, impôs-se em graus diferentes nos veículos de comunicação, de acordo com projetos diferenciados, não sendo uma realidade generalizada, apesar de hegemônica no discurso sobre o jornalismo.

Fazendo um contraponto nessa generalizada tentativa de objetividade dos textos jornalísticos, tem-se o cronista que, juntamente com uma equipe de articulistas e colunistas, atua como uma espécie de reforço da linha editorial do jornal, reduzindo o efeito de absolutização da leitura. A crônica é, efetivamente, a janela da pluralidade, pela reprodução do real e (re)criação de gêneros discursivos.

Nesse sentido, qual a conseqüência da presença de textos assumidamente subjetivos, como a crônica, publicadas no jornal? Parece-nos que, ao mesmo tempo em que se aprofunda a tendência da imprensa à padronização industrial, à brevidade, à rapidez característica das mídias eletrônicas, vê-se consolidar também uma outra tendência, a de ampliação do espaço conferido a autores.

A proliferação e a homogeneização das informações, produzidas cada vez mais em maior quantidade e distribuídas por agências de notícias, além de acessíveis em todos os lugares, contribui para a necessidade de diferenciação pela subjetividade. As notícias parecem todas iguais. O que fará o leitor optar por um veículo, ou mesmo continuar a ler notícias ao invés de abandoná-las por cansaço e tédio? Talvez os pontos de vista pessoais que os jornais se dispunham a oferecer-lhe sejam capazes de costurar o emaranhado de fatos em abordagens mais esclarecedoras, ainda que pessoais ou partidárias - ou exatamente por isso. Assim, formas próximas do literário, como a crônica, têm o papel de antídoto para a fragmentação do 
jornalismo e sua contraditória pretensão de esgotar os fatos, contribuindo ainda no sentido de evitar a simulação de imparcialidade que tende a absolutizar interpretações e vedar a pluralidade de vozes.

\section{Crônica: discurso, história e memória}

Ao empreender um estudo sobre a crônica, constata-se, de imediato, que essa produção discursiva, se comparada a outras, compreende uma tipologia híbrida e complexa, porque apresenta especificidades de um gênero que recria um discurso sobre um fato ou acontecimento sob determinada perspectiva e condições de produção.

Dadas as limitações impostas pelo veículo de comunicação utilizado, a produção de uma crônica jornalística possui condições de tempo e espaço previamente determinados, ou seja, o cronista tem horário determinado para entregar a crônica à publicação, assim como tem de adequar o texto produzido ao espaço da página do jornal, respeitando a diagramação previamente estabelecida.

Pelo fato desses acontecimentos estarem relacionados ao contexto social e, ao mesmo tempo, histórico, esse gênero textual faz, na verdade, o registro do movimento dos homens na construção da sua história, via discurso. Por isso, o estatuto de um fato histórico é adquirido levando em consideração o contexto e o sistema de referência em que se encontra inserido. Dessa forma, a história pode ser tanto o discurso histórico, o texto que organiza um determinado modo de entender os acontecimentos, como também a práxis da qual ele é componente e resultado.

Portadora de um estatuto cristalizado, a crônica ganha, na mídia jornalística impressa, elementos caracterizadores e de referencialização próprios, compreendidos no entrecruzamento do acontecimento/história/memória, cujos sentidos são depreendidos através da interpretação dos recursos lingüístico-discursivos nela empregados. A materialidade lingüístico-discursiva que a constitui sobredetermina uma tipologia singular por apresentar marcas e procedimentos que tornam esse gênero "uma arqui-representação dos lugares em que os interlocutores se colocam comunicativamente no discurso acionado" (Gregolin, 1997), uma vez que os sentidos nela veiculados revelam-se dialogicamente no interdiscurso e na intertextualidade com outros textos, inseridos no mesmo veículo de comunicação. A crônica comporta, nessa perspectiva, uma das principais características desse meio de comunicação impresso - a questão do valor temporal de cada publicação. Como se sabe, o valor de um jornal tem a duração de 24 horas, e esse é um aspecto relevante na consideração das condições de produção da crônica jornalística. 
Assim, se de um lado, constatam-se elementos como agilidade, criatividade e humor, de outro, são imprescindíveis os traços da memória discursiva que se fazem presentes nessa produção.

O nível qualitativo dos efeitos de sentido decorre, então, do entrecruzamento do discurso atual com o discurso histórico. O cronista é, nesses termos, aquele que traz o passado ao presente e recorre, para esse fim, às marcas lingüístico-discursivas deixadas por outros e estabelece pelo dialogismo ${ }^{4}$ a interação entre ele (locutor) e leitor (interlocutor).

Outro componente relevante na constituição do discurso da crônica é o humor. Segundo Beth Brait (1996), esse recurso, numa perspectiva reflexiva e como traço de linguagem, pode revelar um ponto de vista, um olhar sobre o mundo que requer tanto do locutor quanto do interlocutor uma competência discursiva especial. São vários os artifícios expressivos que podem contribuir para esse fim, dentre eles, a ironia. $\mathrm{Na}$ crônica jornalística, a ironia é articulada como estratégia de linguagem que se revela tecnicamente eficaz porque estabelece, nessa tipologia, relações interdiscursivas, podendo dessacralizar "o discurso oficial ou efetuar o desmascaramento de uma pretensa objetividade em discursos tidos como neutros" (Brait, 1996, p. 15).

Num primeiro "olhar", a ironia pode apresentar-se tanto como metáfora, quando corresponde à semelhança de dois objetos, quanto metonímia, numa relação de contigüidade espacial ou temporal. Brait (1996) assinala que a presença da ironia na crônica implica: o locutor (A1) dirige um certo discurso irônico para um receptor (A2), para caçoar de um terceiro (A3) que é o alvo da ironia (Brait, 1996, p. 61-62).

Entendemos que há muito ainda a se falar sobre a crônica moderna - e sem a pretensão de exercitar teoria/crítica literária - acreditamos que, resumidamente, os principais marcos de referencialização e caracterização da crônica, são: a heterogeneidade de gênero, os acontecimentos, a história e a memória.

\section{Do jornal para o livro}

\footnotetext{
${ }^{4}$ O processo de compreensão do enunciado é visto por Bakhtin (1979) como uma relação que envolve os participantes e onde quem compreende torna-se o "terceiro" no "diálogo". O primeiro é o locutor; o segundo é o destinatário próximo, de quem se espera uma compreensão responsiva; e o terceiro é o "superdestinatário superior", de quem o locutor prevê uma compreensão responsiva ideal e que pode adquirir, dependendo da época, "uma identidade concreta variável (Deus, a verdade absoluta, o julgamento da consciência humana imparcial, o povo, o julgamento da história, a ciência, etc)", porque para todo discurso é imprescindível uma resposta. Na busca pela compreensão, o discurso vai longe, torna-se um elo, entra em um diálogo em que o sentido, além de não ter mais fim, contém toda a memória coletiva do dizer (Bakhtin, 1979, p. 356). Portanto, para Bakhtin a produção do discurso envolve um trio, composto pelo autor, pelo destinatário e por todas as vozes-outras que sempre-já nele habitavam, pois o "diálogo" é o acontecimento do encontro e interação com a palavra do(s) outro(s). A alteridade é, para o autor, um processo dialógico em que o elemento comum é o discurso.
} 
Entendendo que a crônica, via discurso, faz o registro dos acontecimentos sociais, fazendo história e resgatando a memória de um povo, a publicação em livro de crônicas é mais do que um marco, é mais do "esticar em livro o efêmero do jornal" - como se justifica Carlos Heitor Cony no prefácio do livro $O$ presidente que sabia javanês ${ }^{5}$. É antes, um registro histórico:

São trabalhos datados, certamente incompreensíveis à geração mais nova. Contudo tiveram razão de ser. (...) além de uma reflexão contrária ao pensamento único do neoliberalismo globalizado, representa um momento de revolta proporcional ao nível de insensibilidade social que domina a cena brasileira neste fim de século. (CONY, 2000, p. 7-8).

Escritas a partir de 1994 e publicadas originalmente na Folha de S. Paulo ${ }^{6}$, as crônicas reunidas em $O$ presidente que sabia javanês, tendo a política nacional intrínseca ao discurso, registram o percurso do sociólogo Fernando Henrique Cardoso: de ministro da fazenda à reeleição presidencial:

É um retrato lúcido e cáustico desses anos de rápidas mudanças, em que o país está definitivamente nas teias da globalização e, segundo Cony, regrediu ao estágio de colônia. (...) temos aqui um retrato em cores vivas e ácidas da era FHC, e especialmente do 'estilo FHC'. (p. 1; trecho da apresentação do livro) ${ }^{7}$.

O que muda nessa transposição do jornal para o livro, já que a crônica publicada em jornal caracteriza-se pelo consumo imediato? Muda a maneira de produzir sentido. No jornal, a crônica estava inserida num contexto noticioso e, portanto, se o leitor não tivesse todo o conhecimento dos fatos/temas tratados na crônica do dia, ele poderia recorrer às reportagens, dialogar com outros textos a fim de produzir os sentidos na crônica. Além disso, o momento histórico estava sendo retratado em tempo real, o que facilita a compreensão. Em livro, os instrumentos necessários para a construção dos sentidos mudam: o leitor precisa recorrer à sua memória discursiva para gerar os efeitos de sentido necessários. O contexto é outro, os fatos abordados pelo jornalismo são outros e o espaço discursivo "livro", onde as crônicas agora estão inseridas, também não é o mesmo. Até o acesso às crônicas é alterado: há que haver uma vontade primordial no leitor para adquirir ou emprestar o livro e realizar a leitura. Vontade essa,

\footnotetext{
${ }^{5}$ Doravante denominado OPQSJ, o livro reúne crônicas publicadas no período 1994-2000, selecionadas por Flamarion Maués e pela editora Ivana Jinkings e vêm acompanhadas com as charges de Angeli. Nossa proposta de análise neste trabalho, no entanto, privilegia apenas o texto verbal e alguns trechos selecionados de acordo com nossos propósitos.

${ }^{6}$ As crônicas publicadas na Folha de S. Paulo adquirem ampla abrangência, uma vez que, além de o jornal ser de circulação nacional, elas são transcritas em outros jornais do país.

${ }^{7} \mathrm{Na}$ apresentação do livro não há indicações de autoria; possivelmente ela foi realizada pela equipe da Editora Boitempo, responsável pela publicação do livro.
} 
que se fundamenta basicamente no desejo de (re) ler as crônicas selecionadas a partir de um determinado tema (como por exemplo, FHC e sua política) e uma sucessividade cronológica.

A análise desenvolvida, a seguir, procura explicitar alguns mecanismos discursivos presentes em trechos selecionados - retirados das 133 crônicas que compõem o livro - os quais ilustram os conceitos anteriormente abordados.

Já numa primeira e "descompromissada" leitura das crônicas como um todo, percebese que há um cruzamento de muitas "vozes" que "falam" nos textos. Essa heterogeneidade fazse presente, inclusive, até na própria escolha do gênero textual ${ }^{8}$ feita pelo autor para materializar o seu discurso. Carlos Heitor Cony - cujo universo discursivo é constituído de muitos campos, o político, o religioso, filosófico, literário etc., os quais são trazidos para o interior de seu discurso - não enuncia o que enuncia nas crônicas de um lugar qualquer. Além de cânone da literatura brasileira, ele está, na enunciação das crônicas, produzindo o seu discurso de outro lugar, de outra posição que também não é comum: jornal Folha de S. Paulo, conceituado meio de comunicação, com abrangência nacional e internacional. É desse "lugar" social e histórico que o autor reveste seu discurso de "autoridade" para refutar o discurso de outra autoridade: FHC.

Em uma das crônicas do livro - O teto e o pão - , o autor afirma não representar nenhuma instituição e apesar de "beliscar ao mesmo tempo na literatura e no jornalismo político", define-se ideologicamente da seguinte maneira:

\begin{abstract}
Diante das misérias humanas, com o fracasso da monarquia e da república, da democracia e da ditadura em realizar a única missão urgente, vendo tanto velho sem teto, tanta criança sem pão, não me restou senão a alternativa de um anarquismo entristecido, humilde e inofensivo. (...) Sem disciplina suficiente para ser de esquerda, sem firmeza necessária para ser de direita, não me sinto confortável na imobilidade tática do centro. O que me sobra seria o anarquismo, que tem dois furos históricos. Primeiro, pressupõe a realização de uma utopia desvairada, a sociedade sem leis nem poder, cada qual cuidando do bem comum como a soma do bem pessoal. Segundo, de tão improvável na prática, o anarquismo gerou através dos séculos a caricatura do cara que joga bombas nas creches, tenta enforcar o último rei com as tripas do último papa. Como nunca tivemos anarquia estruturalmente definida e operada racionalmente, por exclusão desdenho a monarquia e a república, a ditadura e a democracia. Fico na minha: o teto e o pão para todos, seja lá como for, desde que com liberdade para ser do contra ou a favor. (CONY, 2000, p. 184).
\end{abstract}

Para manifestar-se "contra" ou "a favor", Cony reveste-se de estratégias discursivas, pondo em cena, em seu próprio discurso, posições diversas, em que o diálogo, as diferentes

\footnotetext{
${ }^{8}$ Essa afirmação, como explicitado anteriormente, se justifica tendo em vista a própria caracterização da crônica como um espaço heterogêneo: nela, convivem, simultaneamente, o pequeno ensaio, o conto, o poema em prosa, a narrativa, a notícia, dentre outros. Acreditamos que é justamente, nessa diferença, que reside identidade da crônica.
} 
vozes se fazem presentes e se constituem no pano de fundo para a materialização do seu discurso. Quais são essas vozes? Como elas são mobilizadas pelo autor?

Segundo Bakhtin (1975), existe uma dialogização interna da palavra que é sempre perpassada pela palavra do outro, é sempre e inevitavelmente também a palavra do outro. Isto significa dizer que o enunciador, para constituir o seu discurso, leva em conta o discurso de outrem, que estará perpassado ao seu. Daí que o diálogo no discurso não pode ser pensado em termos de relações lógicas ou semânticas, mas sim em termos de posições de sujeitos sociais, pontos de vista acerca da realidade. Portanto,

Todo discurso concreto (enunciação) encontra aquele objeto para o qual está voltado sempre, por assim dizer, já desacreditado, contestado, avaliado, envolvido por sua névoa escura ou, pelo contrário, iluminado pelos discursos de outrem que já falaram sobre ele. O objeto está amarrado e penetrado por idéias gerais, por pontos de vista, por apreciações de outros e por entonações. Orientado para seu objeto, o discurso penetra neste meio dialogicamente perturbado e tenso de discursos de outrem, de julgamentos e de entonações. Ele se entrelaça com eles em interações complexas, fundindo-se com uns, isolando-se de outros, cruzando com terceiros; e tudo isso pode formar substancialmente o discurso, penetrar em todos os seus estratos semânticos, tornar complexa a sua expressão, influenciar todo o seu aspecto estilístico. $\mathrm{O}$ enunciado existente, surgido de maneira significativa num determinado momento social e histórico, não pode deixar de tocar os milhares de fios dialógicos existentes, tecidos pela consciência ideológica em torno de um dado objeto de enunciação, não pode deixar de ser participante ativo do diálogo social (BAKHTIN, 1975, p. 86).

Esse dialogismo mostra-se na bivocalidade, na polifonia, no discurso direto, indireto e indireto livre, dentre outras manifestações construídas a partir de marcas lingüísticas. No texto A pessoa que fala no romance, Bakhtin trata justamente das diversas formas de transmissão do discurso de outrem e de sua relevante participação dos objetos do discurso. Para ele, no discurso de qualquer pessoa que vive em sociedade, em média, pelo menos metade de todas as palavras são de outrem. Para isso, basta prestar atenção às palavras que se ouvem por toda parte e se terá essa confirmação:

Ouve-se no cotidiano, a cada passo, falar do sujeito que fala e daquilo que ele fala. Pode-se mesmo dizer: fala-se no cotidiano sobretudo daquilo que os outros dizem transmitem-se, evocam-se, ponderam-se, ou julgam-se as palavras dos outros, as opiniões, as declarações, as informações; indigna-se ou concorda-se com elas, discorda-se delas, refere-se a elas, etc. Se prestarmos atenção aos trechos de um diálogo tomado ao vivo na rua, na multidão, nas filas, no hall etc, ouviremos com que freqüência se repetem as palavras "diz", "dizem", "disse", e freqüentemente escutando-se uma conversa rápida de pessoas na multidão, ouve-se como que tudo se juntar num único "ele diz", "você diz", "eu digo"... E como é importante o "todos dizem" e o "ele disse" para a opinião pública, a fofoca, o mexerico, a calúnia, etc. (...) A todo instante se encontra nas conversas "uma citação" ou "uma referência" àquilo que disse uma determinada pessoa, ao que "se diz" ou àquilo que "todos dizem", às palavras de um interlocutor, às nossas próprias palavras anteriormente ditas, a um jornal, a um decreto, a um documento, a um livro, etc. A maioria das informações e opiniões não são transmitidas geralmente, em forma direta, originária do próprio falante, mas referem-se a uma fonte geral indeterminada: "ouvi dizer", "consideram", "pensam" etc. (BAKHTIN, 1975, p. 139-40). 
É importante ressaltar que esse discurso de “outrem”, como afirma Bakhtin, não é simplesmente mera repetição. Segundo o autor, é preciso considerar não somente as formas de representação (formalização sintática), mas os procedimentos de transmissão que podem ser muitos variados: pode ser transmitido em todos os níveis possíveis de exatidão e imparcialidade, como também pode sofrer um "enquadramento interpretativo", "reconsideração", "reacentuação", "deformação paródica" e até "deturpação". A esse enquadramento do discurso de outrem, Bakhtin (1975) chama de "transmissão interessada de caráter prático":

\begin{abstract}
É necessário observar o seguinte: por maior que seja a precisão com que é transmitido, o discurso de outrem incluído no contexto sempre está submetido a notáveis transformações de significado. O contexto que avoluma a palavra de outrem origina um fundo dialógico cuja influência pode ser muito grande. Recorrendo a procedimentos de enquadramento apropriados, pode-se conseguir transformações notáveis de um enunciado alheio, citado de maneira exata. O polemista inescrupuloso e hábil sabe perfeitamente que fundo dialógico convém dar às palavras de seu adversário, citadas com fidelidade, a fim de lhes alterar o significado. É particularmente fácil, manipulando-se o contexto, elevar o grau de objetividade da palavra de outrem, provocando reações dialógicas ligadas à objetividade; assim, é muito fácil tornar cômica a mais séria das declarações. A palavra alheia introduzida no contexto do discurso estabelece com o discurso que a enquadra não um contexto mecânico, mas uma amálgama química (no plano do sentido e da expressão); o grau de influência mútua do diálogo pode ser imenso. Por isso, ao se estudar as diversas formas de transmissão do discurso de outrem, não se pode separar os procedimentos de seu enquadramento contextual (dialógico): um se relaciona indissoluvelmente ao outro (BAKHTIN, 1975, p. 141).
\end{abstract}

Essa "transmissão interessada de caráter prático" merece destaque no contexto discursivo das crônicas que estão sendo analisadas, uma vez que Carlos Heitor Cony, ao enquadrar o discurso de outrem, efetua - como afirmara Bakhtin - transformações de significado: polemiza, ironiza, refuta, re-acentua, deforma, enfim, o autor realiza o "enquadramento interpretativo" dos discursos alheios, gerando novos significados.

A partir desses preceitos bakhtinianos, a Análise do Discurso (comumente denominada AD) ${ }^{9}$ propõe o princípio da heterogeneidade: idéia de que a linguagem é heterogênea, isto é, de que o discurso é tecido a partir do discurso do outro, que é o "exterior constitutivo", o "já dito" sobre o qual qualquer discurso se constrói. Isto, para Jacqueline Authier-Revuz (1990, p. 25-

\footnotetext{
${ }^{9}$ Referimo-nos à Análise do Discurso francesa que surge logo após as turbulências políticas do final dois anos 60 , refletindo uma tentativa de se pensar mais profundamente a respeito dos poderes políticos do discurso, bem como de se encarar a linguagem de forma crítica. A fundação da AD francesa, de acordo com Maldidier (1994) está centrada no lingüista Jean Dubois e no filósofo Michel Pêcheux. A proposta inicial de Pêcheux (publicada originalmente na França em 1969) encontra-se traduzida para o português, no texto: Pêcheux, M. Análise automática do discurso (AAD-69). In: Gadet, F. \& Hak, T. (orgs.) Por uma análise automática do discurso: uma introdução à obra de Michel Pêcheux. Campinas, Editora da Unicamp, 1990. Pêcheux \& Fuchs reformulam alguns conceitos da AD em 1975: PÊCHEUX, M. \& FUCHS, C. A propósito da análise automática do discurso: atualização e perspectivas. In: Gadet, F. \& Hak, T. (orgs.) Por uma análise automática do discurso: uma introdução à obra de Michel Pêcheux. Campinas, Editora da Unicamp, 1990.
} 
27), significa dizer que o discurso não opera sobre a realidade das coisas ${ }^{10}$ mas sobre outros discursos, uma vez que todos são "atravessados", "ocupados", "habitados" pelo discurso do outro. Daí que o discurso é fundamentalmente, constitutivamente, heterogêneo: sob a palavra, há outras palavras.

Nesse sentido, Carlos Heitor Cony traz para o contexto das crônicas de OPQSJ essa propriedade de enunciação fazendo ouvir as diferentes vozes - para retomar os termos de Mikhail Bakhtin - ou, como afirma Authier-Revuz, os outros (outros enunciadores, outros discursos).

\section{Ironia e carnavalização}

Entre as formas de heterogeneidade constitutiva ${ }^{11}$ que mais se destacam nas crônicas de OPQSJ está a ironia. Porém, antes de citar alguns exemplos dessa modalidade de construção discursiva. A ambigüidade, a inversão de papéis e o caráter polemizador, genericamente, são a essência da ironia. No entanto, outro aspecto importante desse recurso é o pressuposto incluso entre autor (enunciador) e leitor (enunciatário). Há a necessidade básica de um campo comum entre eles para se forjar a polêmica e instaurar a ironia:

Os sinais contextuais, portanto de ordem enunciativa, promovem no plano da significação uma cumplicidade entre o enunciador e o enunciatário [no caso, autor e leitor, respectivamente], de tal modo que imediatamente o leitor pode compreender que aquilo que o locutor assume e enuncia como fato é a tradução de um desejo coletivo e não uma realidade. Daí o efeito de humor. (...) É evidente que nessa duplicidade, esse jogo de presença/ausência que configura o processo irônico, passa (...) pelo cruzamento de discursos compartilhados entre enunciador e enunciatário. (BRAIT, 1996, p. 59).

Complementando, Brait afirma que o locutor encontra formas de chamar a atenção do interlocutor para o discurso e, por meio desse procedimento, contar com a sua adesão. Sem esse mecanismo discursivo de interpelação-adesão, a ironia não se realizaria. O conteúdo da ironia estará subjetivamente marcado por valores atribuídos pelo locutor, mas apresentados de forma a exigir a participação do interlocutor, sua perspicácia para reconhecer sinalizações - algumas vezes extremamente sutis - inscritas no enunciado:

\footnotetext{
${ }^{10}$ Para Bakhtin/Volochinov (1929), o discurso não só refrata e intervém no real, como também refere o real.

${ }^{11}$ Segundo Authier-Revuz (1990), a heterogeneidade pode ser constitutiva ou mostrada. A primeira é aquela que não se mostra no fio do discurso, em que o discurso não revela a alteridade na sua manifestação. A segunda - que pode ser marcada ou não marcada - é a inscrição do outro na cadeia discursiva, alterando sua aparente unicidade e exibindo a alteridade ao longo do processo discursivo. A heterogeneidade mostrada pode ser marcada, quando se circunscreve explicitamente por meio de marcas lingüísticas a presença do outro.
} 
A crônica exige que o leitor desvende esse jogo de presença/ausência para ter os seus sentidos desvelados. Entre outros elementos desse jogo, estão como importantes os lugares de enunciação ou os locutores nomeados no texto. Há a pressuposição entre enunciador e enunciatário de conhecimento desses personagens para a compreensão dos enunciados forjados a partir desses lugares. Para ler outros textos, e especificamente a crônica, é necessário desvelá-los para compreender os sentidos ali impressos. O que nos leva à necessidade de uma definição clara de ironia como (...) o discurso que pretende significar o contrário do que é dito literal ou explicitamente e que, nessa perspectiva, também está ligada à definição de ironia como antífrase. (BRAIT, 1996, p. 72-73).

Semelhante inversão não é nada gratuita. A ironia é um recurso tradicional de destronamento e de polêmica de um outro discurso já estabelecido. Ao aprofundar a análise dessa relação intersubjetiva que se estabelece no processo de construção da ironia, a autora também afirma que, qualquer que seja sua dimensão, o irônico desencadeia um jogo entre o que o enunciado diz e o que a enunciação faz dizer, com o objetivo de desmascarar ou subverter valores, processo que, necessariamente, conta com o envolvimento do interlocutor:

Constituindo um fenômeno bivocal, dialógico, um sistema de interação, para utilizar os termos de Bakhtin, as formas de recuperação do já-dito com objetivo irônico não assumem, como tal, a função de erudição, no sentido de invocação de autoridade e muito menos de simples ornamento. Ao contrário, são formas de contestação de autoridade, de subversão de valores estabelecidos (...) (BRAIT, 1996, p. 108).

Além disso, a ironia exige, necessariamente, a opacificação do discurso, na medida em que o locutor "produz um enunciado de tal forma a chamar a atenção não apenas para o que está dito, mas para a forma de dizer e para as contradições existentes entre as duas dimensões" (id. ibidem). Nesse sentido, Beth Brait ressalta que a ironia é uma forma de citação, o locutor convoca para o seu enunciado - sob a forma de alusão ou de paródia - um universo axiológico (coletivo ou individual) estabelecido em outros discursos e com o qual ele não compartilha. Nesse diálogo entre discursos, ou a maneira de um discurso lidar com os outros, evidencia-se a interdiscursividade irônica. É o que se pode perceber na crônica $O$ muro e a previdência:

Os trabalhadores de uma empresa vinculada a poderoso grupo internacional estavam seis meses sem receber salários. Fizeram greve. Depois das negociações habituais, o piquete grevista ameaçou depredar alguns equipamentos. Chamaram o presidente da holding - que devia o seu cargo, entre outros méritos, ao fato de saber tratar dessas questões. O empresário mandou entrar em seu escritório um comitê de seis representantes dos grevistas, serviu cafezinho e água gelada, distribuiu uma flâmula da campanha contra os acidentes no trabalho e, em tom paternal, perguntou: "Meus filhos, vocês não sabem que o Muro caiu?" De início, os grevistas não entenderam que muro era. Eles queriam receber seis meses de salário, somente isso. A que muro o patrão se referia? "Ao de Berlim, meus filhos, o socialismo já era, faliu vergonhosamente, vocês estão na contramão da história etc. etc. (CONY, 2000, p. 17, grifo nosso). 
Na construção irônica dessa crônica, o locutor dialoga com outros discursos, jogando argumentativamente com a memória discursiva do interlocutor. Remetendo ao discurso bíblico/paternal, o locutor recorre a associações entre os "trabalhadores em greve" e "meus filhos". É o discurso moral da parábola aqui presente: o empresário revestido de "pai" (aquele que detém grande sabedoria) falando ao "filho" (jovem rebelde e que necessita de ensinamentos). Há também a alusão ao capitalismo e à decadência do socialismo na Alemanha, o que exige que o interlocutor reconheça essas ligações e transfira os sentidos para o momento histórico da enunciação; desse modo, por uma espécie de cálculo interpretativo, o interlocutor instaura os efeitos de sentido/ironia. Isso nos mostra que, na consideração do sentido irônico no discurso, envolve-se, tanto o procedimento discursivo do locutor, que deseja que sua ironia seja percebida, quanto as atribuições de sentido feitas pelo interlocutor.

Faz-se necessário, também, posicionar outros conceitos de Mikhail Bakhtin que se mostram valiosos para o presente trabalho, uma vez que a ironia em OPQSJ, nesse jogo de subversão de valores e discursos estabelecidos, pode ser lida pelo viés da carnavalização.

$\mathrm{Na}$ crítica elaborada por Bakhtin da obra de Fiódor Dostoiévski, especialmente as concernentes ao gênero de origem helênica "menipéia", o teórico russo desdobra a análise desse gênero em 14 particularidades. Apesar de ser um gênero historicamente circunscrito ao universo literário, Bakhtin aponta que "a derradeira particularidade da menipéia é sua publicística $^{12}$ atualizada. Trata-se de uma espécie de gênero ‘jornalístico’ da Antigüidade, que enfoca em tom mordaz a atualidade ideológica" (Bakhtin, 1963).

Para tanto, ele observa que as sátiras de Luciano são uma "autêntica enciclopédia da sua atualidade":

(...) são impregnadas de polêmica aberta e velada com diversas escolas ideológicas, filosóficas, religiosas e científicas, com tendências e correntes da atualidade, são plenas de imagens de figuras atuais ou recém-desaparecidas, dos "senhores das idéias" em todos os campos da vida social e ideológica (citados nominalmente ou codificados), são plenas de alusões a grandes e pequenos acontecimentos da época, perscrutam as novas tendências da evolução do cotidiano, mostram os tipos sociais em surgimento em todas as camadas da sociedade, etc. Trata-se de uma espécie de "Diário de um escritor", que procura vaticinar e avaliar o espírito geral e a tendência da atualidade em formação. (BAKHTIN, 1963, pp. 118-119).

Bakhtin (1963) destaca que esse gênero se apresenta em fases de profundas transformações sociais:

Ele se formou na época da desintegração da tradição popular nacional, da destruição daquelas normas éticas que constituíam o ideal antigo do 'agradável' ("belezadignidade"), numa época de luta tensa entre inúmeras escolas e tendências religiosas e filosóficas heterogêneas, quando as discussões das "últimas questões" da visão de

12 Segundo nota do tradutor "o termo é empregado pela crítica soviética como gênero literário ou literatura político-social centrada em temas da atualidade” (BAKHTIN, 1963, p. 118). 
mundo se converteram em fato corriqueiro entre todas as camadas da população e se tornaram uma constante em toda a parte onde quer que se reunisse gente: na praça pública, nas ruas, estradas, tavernas, nos banhos, no convés dos navios. (BAKHTIN, 1963, p. 119).

Os elementos acima arrolados têm correspondência ao trabalho de Carlos Heitor Cony como cronista político-social. As transformações, bem como as constantes crises pelas quais o país tem passado e a instauração de mudanças no âmbito político/social brasileiro, especialmente na "era FHC", constituem-se o enfoque primordial do autor.

As crônicas jornalísticas - em particular o corpus aqui analisado - estão marcadas pelo diálogo com o seu tempo. Se até a Idade Média esses conflitos tinham como palco privilegiado a discussão das "últimas questões" nas praças e outros espaços públicos, em nossa contemporaneidade semelhante quadro tem uma caixa de ressonância nos grandes veículos de comunicação. Carlos Heitor Cony discute nas crônicas de OPQSJ o momento político-social dessa fase, 1994 a 2000, os valores que emergem nessa época, colocando-os em contraponto com os anteriores, valendo-se de sua memória vivida, polemizando, assim, as questões sociais e as atitudes políticas.

Essa questão do jogo de vozes representando lugares ideológicos distintos é também estudada por Bakhtin (1963) e denominada de carnavalização literária. O autor a localiza como uma linguagem em que, a exemplo do festejo popular, eliminam-se:

(...) as leis, proibições e restrições, que determinavam o sistema e a ordem da vida comum, isto é, extra-carnavalesca, revogam-se durante o carnaval: revogam-se antes de tudo o sistema hierárquico e todas as formas conexas de medo, reverência devoção, etiqueta, etc., ou seja, tudo o que é determinado pela desigualdade social hierárquica e por qualquer outra espécie de desigualdade (inclusive a etária) entre os homens. (BAKHTIN, 1963, p. 123).

Assim, um dos elementos básicos desse processo é a coroação-destronamento como:

Um ritual ambivalente biunívoco, que expressa a inevitabilidade e, simultaneamente, a criatividade da mudança-renovação, a alegre relatividade de qualquer regime ou ordem social, de qualquer poder e qualquer posição (hierárquica). Na coroação já está contida a idéia do futuro destronamento; ela é ambivalente desde o começo. Coroase o antípoda do verdadeiro rei - o escravo ou o bobo, como que inaugurando-se e consagrando-se o mundo carnavalesco às avessas ${ }^{13}$. Na cerimônia de coroação, todos os momentos do próprio ritual, os símbolos do poder que se entregam ao coroado e a roupa que ele veste tornam-se ambivalentes, adquirem o matiz de uma alegre relatividade, tornam-se quase acessórios (mas acessórios rituais); o valor simbólico desses elementos se torna biplanar (como os símbolos reais do poder, ou seja, no mundo extracarnavalesco, são monoplanares, absolutos, pesados e monoliticamente sérios) (BAKHTIN, 1963, pp. 124-5, grifo nosso).

${ }^{13}$ Nesse sentido, Mikhail Bakhtin aponta para a importante inversão de hierarquia que se estabelece pela carnavalização. 
A última característica da carnavalização, senão meta primordial, é o riso e o seu papel básico: o riso não como forma exterior, mas o riso interior, essencial e que não pode ser substituído pelo sério, sob a pena de destruir e desnaturalizar o seu próprio conteúdo de verdade revelada por meio do riso que se liberta não apenas da censura exterior, mas do censor interior que existe no próprio homem.

Para construir sua discursividade irônica em torno de FHC e seu governo, Carlos Heitor Cony subverte a fronteira entre o que é assumido e o que não o é por ele (locutor), carnavaliza discursos e posturas políticas e ridiculariza a realidade através da linguagem ambígua e mordaz, rompendo com o monológico:

\begin{abstract}
Impressionantes os recuos do governo. Não há semana em que o presidente da República não seja docemente constrangido a mudar de idéia ou de rumo. Docemente, também, ele explica que o recuo não vai interferir no seu programa e propósitos. FHC levou para o poder 34 milhões de votos e apenas um equívoco que anula todos esses mandatos da expressão popular. Ele deve acreditar que votaram nele, FHC, professor, homem de bem, boa praça, simpaticão, cordato etc. Até eu torceria para que isso fosse verdade. (CONY, 2000, p. 22, grifo nosso).
\end{abstract}

Nessa crônica (Fisiologismo ideológico), o locutor dialoga com as mudanças constantes dos propósitos de FHC enquanto governo, versus propostas apresentadas durante a campanha. Independente do sentido irônico produzido, é interessante focalizar a movimentação lingüístico-discursiva empreeendida pelo locutor. Por meio da expressão “docemente ${ }^{14}$ constrangido (...)", e "docemente também ele explica (...)" o locutor cria uma cena enunciativa antecipatória, apontando para um jogo lingüístico marcado pela ambigüidade do enunciado. O contexto da crônica oferece pistas para a compreensão irônica do enunciado. O leitor (interlocutor) é convidado a reconhecer que FHC não é “meigo, doce”, mas apresentase como tal para tentar esquivar-se dos compromissos assumidos e não postos em prática: é a caracterização do lobo em pele de cordeiro. Outra compreensão possível deste "docemente" refere-se à resignação, aceitação a tudo e submissão a muitos a ponto de não conseguir governar, mas ser governado.

\title{
Conclusão
}

Buscamos salientar neste trabalho o conceito híbrido que caracteriza a crônica contemporânea que pode ser compreendida também como uma zona de miscigenação do discurso jornalístico com várias outras formas discursivas, provocando um grande diálogo de

\footnotetext{
${ }^{14}$ Oportuno ressaltar que alguns termos são recorrentes na construção discursiva do autor ao referir-se a FHC e esse termo "docemente"/ "doce" é um deles, inclusive para referir-se à primeira-dama.
} 
pensamentos nos veículos de comunicação. Além disso, a crônica como discurso de um dado momento histórico, traz em si o imaginário dessa época, atuando inclusive, como uma forma diferenciada de documento para pesquisadores. Realizando, o registro dos acontecimentos sociais, fazendo história e resgatando a memória de um povo, a crônica retrata discursivamente uma dada época via meio jornalístico impresso. Por intermédio da publicação das crônicas em livro inscreve-se, mesmo que resumidamente, a crítica das transformações pelas quais passa o país. Portanto, é mais do que um marco, é mais do "esticar em livro o efêmero do jornal".

\section{Referências}

ARRIGUCCI JÚNIOR, D. Enigma e comentário: ensaios sobre a literatura $e$ a experiência. São Paulo: Companhia das Letras, 1987.

AUTHIER-REVUZ, J. (1990) Hetrogeneidade(s) enunciativa(s). Cadernos de Estudos lingüísticos. Campinas, UNICAMP/IEL, n. 19, 1990.

BAKHTIN, M. (1979) Estética da criação verbal. 3.ed. São Paulo: Martins Fontes, 2000. (1963) Problemas da poética de Dostoiévski. 2. ed. Rio de Janeiro: Forense Universitária, 1997.

. (1975) Questões de literatura e estética (a teoria do romance). 5. ed. São Paulo: Hucitec/Editora da UNESP, 2002.

(VOLOCHINOV) (1929) Marxismo e filosofia da linguagem. 9. ed. São Paulo: Hucitec, 1999

BRAIT, B. Ironia em perspectiva polifônica. Campinas: Editora da Unicamp, 1996.

CANDIDO, A. [et al] A crônica: o gênero, sua fixação e suas transformações no Brasil. Campinas: Editora da Unicamp; Rio de janeiro: Fundação Casa de Rui Barbosa, 1992. CONY, C. H. e ANGELI. O presidente que sabia javanês. São Paulo: Boitempo, 2000.

COUTINHO, A. Introdução à literatura no Brasil. 9. ed. Rio de Janeiro: Civilização Brasileira, 1978.

GREGOLIN, M. R. V. Discurso e memória: movimentos na bruma da História. In: POSSENTI, S., CHACON, L. (Orgs.) Cadernos da FFC: Análise do Discurso. (Marília), n.2, v.6, p. 45-58, 1997.

SÁ, J. de. A crônica. 6. ed. São Paulo: Ática, 2002.

SILVA, C. E. L. O adiantado da hora: a influência americana sobre o jornalismo brasileiro. São Paulo: Summus, 1991. 